\title{
МОВНІ ЗАСОБИ РЕАЛІЗАЦІї ДИХОТОМІЇ “ТОЛЕРАНТНІСТЬ / ВОРОЖІСТЬ" У ЗМК
}

\author{
ЛЮДМИЛА МАРЧУК \\ Кам'янець-Подільський національний університет імені Івана Огієнка, \\ Кам'янець-Подільський - Україна \\ lyudmylamarchuk60@gmail.com; ORCID: 0000-0002-9022-2103 \\ JEZYKOWE SPOSOBY REALIZACJI \\ DYCHOTOMII "TOLERANCJA / WROGOŚĆ" \\ W ŚRODKACH KOMUNIKACJI MASOWEJ \\ LUDMYŁA MARCZUK \\ Narodowy Uniwersytet imienia Iwana Ohijenki w Kamieńcu Podolskim, \\ Kamieniec Podolski — Ukraina
}

STRESZCZENIE. Artykuł poświęcony jest aktualnej w dzisiejszych czasach kwestii dychotomii „tolerancja - wrogość”, mającej miejsce w okresie radykalnych przemian społecznych, nasilenia się konfliktów międzyetnicznych i międzyreligijnych, kształtowania się relacji między ludźmi i państwami, opartych na zasadach humanitaryzmu. To wiąże się ze znacznym zainteresowaniem wyżej wymienioną kwestią, potrzebą wyznaczenia jej istoty, znalezieniem skutecznych form i metod edukacji osobowości tolerancyjnej.

Słowa kluczowe: tolerancja, wrogość, dychotomia, norma językowa, token jądrowy.

\section{LANGUAGE MEANS OF DICHOTOMY REALIZATION \\ OF "TOLERANCE / HOSTILITY" IN WAYS \\ OF COMMUNICATION OF MASS MEDIA}

\section{LIUDMYLA MARCHUK \\ Kamianets-Podilskiy Ivan Ohiyenko National University, Kamianets-Podilskiy — Ukraine}

ABSTRACT. The article deals with the description of the problem of tolerance and hostility that takes place during the period of a radical social change, the intensification of the inter-ethnic and interreligious conflicts, the establishment of the humane relations between people and states, all of which are characteristic features of modernity, which entails a considerable interest in defining the essence of these concepts, the development of the effective forms and methods of education, a tolerant personality.

Key words: tolerance, hostility, dichotomy, linguistic norm, nuclear token.

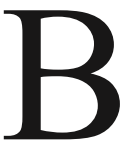

ажливим напрямком дослідження сучасних медіатекстів $є$ порівневий аналіз мовних засобів реалізації комунікативних стратегій. У цій статті розглядаємо дихотомію толерантність / ворожість як сукупність мовних засобів та стилістичних прийомів, що пом'якшують або посилюють негативну оцінку чи інтенції адресанта та служать додатковими засобами досягнення мети комунікації. Толерантність та ворожість - багатопланові категорії, зреалізовані на всіх рівнях мови, починаючи від лексичного, найбільш експлікованого, та закінчуючи синтаксичним.

У СУМі натрапляємо на таке тлумачення ядерних лексем зазначеної дихотомії: „ТОЛЕРА́НТНИЙ, a, е, книжн. Поблажливий, терпимий до чиїхсь думок, 
поглядів, вірувань тощо”; „ВОРО́ЖІСТЬ, жості, жін. Властивість за значенням ворожий'?

Категорія толерантності була предметом аналізу учених різних напрямків, напр., політологів ${ }^{3}$. Проте толерантність, на нашу думку, це ментальна категорія; предметом іiі дослідження мають стати ономасіологічні, прагматичні ознаки, властивості, функції.

Толерантність — це напівкалька $з$ лат. tolerans / tolerantis; tolerantia ‘той, що терпеливо переносить', ‘терпіння', ‘терплячий', що означає реакцію людини з боку зовнішнього світу.

С. Караванський зазначив такий синонімічний ряд: „ТЕРПЕЛИВИЙ, ТЕРПЛЯЧИЙ, г. виде́ржливий; (верблюд) витрива́лий; (до вад) виба́чливий, толера́нтний; (до мук) довготерпели́вий, с. стражде́нний, терпли́вий"4. Якщо порівнювати терпимість і толерантність, то за цими ознаками можна поставити між ними не знак рівності, a $>$. Оскільки терпимість має більше семантичне наповнення, то толерантність виявляється лише частковим синонімом до лексеми терпимість. Проте, з позиції ціннісної категорії, толерантність > за терnuмiсть, позаяк демонструє активну миролюбиву позицію комуніканта, тоді як терпимість - пасивну позицію непротивлення.

У мові регіональних ЗМК натрапляємо на опис таких видів толерантності: 1) релігійної; 2) поведінкової; 3) національної; 4) соціальної; 5) політичної. Приклади з ЗМК підтверджують та розширюють семантику толерантності, зображають іiі як цивілізований компроміс, готовність допускати іншодумство. Напр., наведемо витяги з публікацій в інтернет-виданнях від 16.11.2016 р. (у день толерантності):

Лілія Омельяненко (Lilia Omelianenko). Співзасновниця благодійного фонду „Добра Листівка". Чому на наших вулицях мало людей з інвалідністю? Я хочу побажати українцям і украӥнському суспільству більше толерантності. Толерантності до прав інших людей: жінок, сексуальних й інших меншин, толерантності до неповносправних людей. Я за своїм родом діяльності більше займаюся проблемами дітей з інвалідністю $і$, на жаль, зараз в Україні ия проблема є досить гострою, бо не всі знають про існування таких людей. Не тому, що їх немає, а тому, що ми просто не можемо бачити їх на вулицях, бо вони не можуть вільно пересуватися. Я досить багато подорожую іниими краӥнами, як зі своєю родиною, так $і$ по роботі, $і$ там такі люди можуть абсолютно вільно відвідувати музеї, гуляти містом, спілкуватися зі своїми друзями, знайомими. Все ие відбувається на вулицях. Люди знають щзо вони є, їм допомагають, і держава також допомагає таким людям розвиватися і бути повноправними членами суспільства. Давайте допоможемо їм розвиватися і в Україні. Вони такі ж люди як і ми й також хочуть жити.

Вадим Логвінов. Заступник директора Національного музею народної архітектури та побуту України (Пирогово). Про етнічну толерантність в Україні. Ми - етнічні українці. Так само ми повинні дати шанс іншим націям, які проживають поруч з нами, які на сьогодні теж є українцями. Украӥнською політичною нацією. С вірмени, які будували Львів $і$ які приїхали пізніше, є євреї,

\footnotetext{
${ }^{1}$ Словник української мови, в 11 томах, Київ 1979, т. 10, с. 179.

2 Там само, т. 1,1970 , с. 740.

${ }^{3}$ С. Логвиненко, Начіональна консолідачія і проблеми толерантності в умовах глобалізації та терористичних загроз, [в:] „Політичні науки та методика викладання соціальнополітичних дисциплін”, Київ 2010, вип. 3, с. 113-118.

${ }^{4}$ С. Караванський, Практичний словник синонімів украйнської мови, Київ 2000, с. 384.
} 
які свого часу приїжджали в Україну, потім були різні ситуації. $С$ якісь гагаузи, караӥми, які більш ніде не зустрічаються, тільки у нас. Ми повинні дати їм шанс зберегтися. Це і є ознакою сучасної толерантності.

Tina Polek. Кандидат iсторичних наук, антрополог. Про толерантність у місті. Якщо ми говоримо про те, чи здатне місто засвоїти велику кількість мігрантів, то здатне, якою б ия кількість не була. Якщо грамотно проводити... це важко назвати політикою, якщо вчити людей толерантності, якщзо показати, щзо мігранти, за висловом того ж Блера Рубла, це не просто приїжджі, ие - капітал розмаїтості. Він говорить про те, щзо будь-хто, хто приїжджає, він приносить частинку свого життесвіту, він приносить частинку свого досвіду, частинку своєї культури, якщо иүе грамотно використати, то ие не тільки не нашкодить місту, ие збагатить місто 5 .

Проте цей концепт елітарного зрізу передається й через протилежну категорію - ворожості. Так, з метою подолання агресії, ксенофобії й мови ворожнечі в ЗМК та соціальних мережах “Детектор медіа” пропонує огляд вітчизняних інтернет-видань, у матеріалах яких трапляються ознаки “мови ворожнечі”.

У новинах і статтях інтернет-видань "Українська правда", “Цензор.нет" i LB.ua та ін. "мова ворожнечі" здебільшого спрямована на мешканців Росії, тимчасово окупованих територій України, внутрішньо переміщених осіб, етнічні групи, людей з наркотичною залежністю, мігрантів без офіційних документів та інших осіб. Ось найбільш яскраві приклади того, як популярні українські інтернет-видання деколи забувають про толерантність.

Інтернет-видання "Українська правда", 9 жовтня 2016 року. Тематика: внутрішньо переміщені особи. Фрагмент: У регіонах, де багато переселениів, стало більше крадіжок - Троян. В Україні відмічається підвищення середньостатистичного зростання крадіжок в регіонах, де сконцентровано більшість переселенців. Про ие пише у своїй статті для DT.UA заступник голови Нациоліиії Вадим Троян

Порушення: цитування нетолерантних висловів, створення негативного образу внутрішньо переміщених або вимушено переселених осіб; згадка про ВПО у негативному криміналізованому контексті.

Оскільки обидві категорії (толерантність / ворожість) пов'язані контрарними зв'язками й мають чітко виражену оцінність, будуємо градаційну оцінну шкалу, де нулем буде лексема байдужість, полюсом зі знаком “_“ ворожість, полюсом зі знаком “+” толерантність. У проміжках між нулем і полюсами лежать такі лексеми: між 0 та + прощення; м'якість; жалість; співчуття; терпіння до інших; чуйність; терпимість; стриманість; ичивілізованість; між 0 та - неприязнь; недоброзичливість; розбрат; антагонізм; ксенофобія; протистояння; ненависть; агресивність; дратівливість; екстремізм. Крім того, у текстах спостерігаємо маркери 'велика толерантність' та 'нульова толерантність'. Нульова толерантність за змістом синонімічна байдужості, а велика толерантність або псевдотолерантність має негативне (-) забарвлення. Напр.: Нульова толерантність до корупиіï, про яку часто згадують у суспільстві, в повсякденному житті зводиться, по суті, до відповіді на просте запитання: чи да-

${ }^{5}$ Толерантність, навіщзо вона нам, [в:] Електронний ресурс: http://idealist.media/index.php/ tolerantnist-navischo-vona-nam (25.03.2017).

${ }^{6}$ Як украйнські інтернет-3МІ забувають про стандарти: кейси з мови ворожнечі, [в:] Електронний pecypc: http://detector.media/infospace/article/126745/2017-06-03-yak-ukrainski-internetzmi-zabuvayut-pro-standarti-keisi-z-movi-vorozhnechi (07.05.2017). 
вати хабара? ${ }^{7}$ (О. Митницька, координатор Українського медіа-центру реформ, 15:50, четвер, 28 липня 2016).

Отже, у ЗМК категорія толерантності / ворожості на лексичному рівні репрезентована як ментальна оцінна дихотомія з позитивно-негативною оцінкою, що описується через синонімічні та антонімічні відношення. Лексем, що задіяні в семантичне поле цих категорій, у ЗМК значно більше, ніж у словниках (тлумачному, синонімів, антонімів). ЗМК також пропонують до лексеми толерантність синоніми компроміс і консенсус. У науковій літературі були виділені різні підходи до розуміння толерантності, в основному це розгляд толерантності як політичної або соціально-культурної необхідності, а також як внутрішньої установки індивіда. Відбувається зрушення фіксованих соціальних установок щодо особистості та ії морально-соціальних цінностей, порушується предиспозиція - оцінювати об'єкт чи символ певним способом — все це змінюється під впливом вербальної інформації.

У результаті проведеного дослідження ми переконалися, що в засобах масової комунікації допускаються порушення моральних норм, норм толерантності, за рахунок чого з'являються висловлювання дискримінаційного характеру.

Після Другої світової війни багато європейських країн стали ухвалювати законодавчі акти, що забороняли “мову ворожнечі". Первинна мета підтримування миру на європейському континенті. Початковою метою таких нормативних актів було приборкати підбурювання до расової та релігійної ненависті. Ці закони первинно були призначені для захисту від ксенофобії та антисемітизму. Зауважимо, що в публічному дискурсі натрапляємо на такі словосполучення для визначення одного явища: "hate speech", “мова ворожнечі", "мова ненависті".

"Мова ворожнечі" - поняття оцінне, оскільки в міжнародному визначенні прав людини не існує загальноприйнятої концепції. Критерії для опису мови ворожнечі також $є$ досить суперечливими через те, що міжнародні та регіональні документи передбачають різні стандарти. Варто зазначити, що велика кількість ознак “мови ненависті” формувалась як реакція на специфічні соціальні явища та інциденти, а також адаптувалася відповідно до українського законодавства.

Якість кожного суспільства залежить від здатності людей співіснувати одне 3 одним, від того, чи сприймають вони одне одного, чи поважають і підтримують, чи навчаються одне в одного, чи об'єднують свої зусилля в ім'я загального добра, для постійного поліпшення свого матеріального й духовного життя. В умовах соціальної розмаїтості дуже важливо встановити культуру миру, що неможливо без дієвого виховання, заснованого на принципах толерантності.

На території України проживали й проживають люди різних національностей 3 властивими їм особливостями духовно-культурного життя. Згодом унаслідок соціальних, економічних та інших взаємодій вони запозичили одне в одного окремі елементи, що стали в такий спосіб спільними для більшості етнічних груп. Разом з тим, в основному вони зберегли свою ідентичність. Унаслідок цих взаємин зародилися споконвічні соціальні уявлення про людей залежно від етнічних, конфесійних, світоглядних та інших відмінностей, що неминуче призвело до появи стереотипів. Відомо, що стереотипи бувають як позитивними, заснованими на повазі, визнанні й підтвердженні чужих цінностей,

${ }^{7}$ О. Митницька, Як інтернет-3МI пишуть про хабарі: дослідження, [в:] Електронний реcypc: http://detector.media/infospace/article/117287/2016-07-28-yak-internet-zmi-pishut-pro-khabaridoslidzhennya (03.03.2017). 
так і негативними, що загрунтовані на відштовхуванні, презирстві чи навіть ненависті. Подолання стереотипу — складний і тривалий процес.

Толерантність є першим щаблем не тільки до запобігання, але й до подолання стереотипів. Діалог, безпосередній контакт - це найкраще джерело інформації про інших, реальний шлях духовного й культурного зближення, інструмент розв'язання різних проблем. Крім того, це відкритість до міжкультурного спілкування, в основі якого лежить повага до особливостей іншого, іншими словами, його ідентичності.

Ненасильницьке спілкування — це здатність зрозуміти, що ти відчуваєш, які емоції переживаєш, і припустити, що відчуває і які емоції переживає інша людина. Це розуміння власних потреб у ситуації і припущення того, які потреби має інша людина.

Убачаємо перспективу дослідження в аналізі вербалізації дихотомії на граматичному рівні та створенні ідеальної моделі поняття толерантність.

\section{Список використаної літератури}

Караванський С., Практичний словник синонімів української мови, Київ 2000.

Логвиненко С., Національна консолідація і проблеми толерантності в умовах глобалізаиії та терористичних загроз, [в:] „Політичні науки та методика викладання соціально-політичних дисциплін”, Київ 2010, вип. 3, с. 113-118.

Митницька О., Як інтернет-3МI пишуть про хабарі: дослідження, [в:] Електронний pecypc: http://detector.media/infospace/article/117287/2016-07-28-yak-internet-zmipishut-pro-khabari-doslidzhennya (03.03.2017).

Словник української мови, в 11 томах, Київ 1970-1979.

Толерантність, навіщо вона нам, [в:] Електронний ресурс: http://idealist.media/index. $\mathrm{php} /$ tolerantnist-navischo-vona-nam (25.03.2017).

Як українські інтернет-3МІ забувають про стандарти: кейси з мови ворожнечі, [в:] Електронний ресурс: http://detector.media/infospace/article/126745/2017-06-03-yakukrainski-internet-zmi-zabuvayut-pro-standarti-keisi-z-movi-vorozhnechi (07.05.2017).

\section{Spysok vykorystanoi literatury [References]}

Karavanskyi S., Praktychnyi slovnyk synonimiv ukrainskoi movy [Practical Dictionary of Synonyms in the Ukrainian Language], Kyiv 2000.

Lohvynenko S., Natsionalna konsolidatsiia i problemy tolerantnosti v umovakh hlobalizatsii ta terorystychnykh zahroz [National Consolidation and Problems of Tolerance under Conditions of Globalization and Terrorist Threats], [v:] „Politychni nauky ta metodyka vykladannia sotsialno-politychnykh dystsyplin”, Kyiv 2010, vyp. 3, s. 113-118.

Mytnytska O., Yak internet-ZMI pyshut pro khabari: doslidzhennia [The Way the I-net Media Write about Bribes: Researches], [v:] Elektronnyi resurs: http://detector.media/infospace/ article/117287/2016-07-28-yak-internet-zmi-pishut-pro-khabari-doslidzhennya (03.03.2017).

Slovnyk ukrainskoi movy [Dictionary of the Ukrainian Language], v 11 tomakh, Kyiv 19701979.

Tolerantnist, navishcho vona nam [Tolerance, what for is it Needed], [v:] Elektronnyi resurs: http://idealist.media/index.php/tolerantnist-navischo-vona-nam (25.03.2017).

Yak ukrainski internet-ZMI zabuvaiut pro standarty: keisy z movy vorozhnechi [The Way the I-net Media Forget about Standards: Cases from the Language Hostility], [v:] Elektronnyi resurs: http://detector.media/infospace/article/126745/2017-06-03-yak-ukrainski-internetzmi-zabuvayut-pro-standarti-keisi-z-movi-vorozhnechi. (07.05.2017). 